\title{
Impacts of dense crab populations on carbon exchanges across the surface of a salt marsh
}

\author{
D. I. Taylor*, B. R. Allanson \\ Institute for Water Research, Rhodes University, PO Box 94, 6140 Grahamstown, Republic of South Africa
}

\begin{abstract}
Laboratory mesocosm experiments were conducted to quantify the effects of 2 crab species, Sesarma catenata and Cleistostoma edwardsii, on carbon exchanges across the surface of a south temperate salt marsh. The grapsoid crab $S$. catenata was most abundant in the vegetated marsh flats, and the ocypodoid $C$. edwardsii in the unvegetated tidal creek. Replicate mesocosms of the marsh flats and tidal creek were incubated with and without crabs of the species dominant in that region. Both species enhanced the losses of carbon relative to uptake by the marsh, but they did so via different mechanisms. In the tidal creek, C. edwardsii increased the net fluxes of total organic carbon (TOC) by $60 \%$

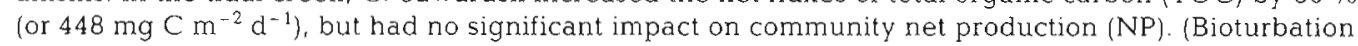
accounted for $95 \%$ of the enhanced TOC fluxes, and excretion only $5 \%$ ). In the marsh flats, S. catenata had no measurable impact on the fluxes of TOC, but decreased community NP by $1132 \mathrm{mg} \mathrm{C} \mathrm{m}^{-2} \mathrm{~d}^{-1}$ (Ninety-two percent of this reduction was caused through reduction in epibenthic NP through crab grazing of microalgae. Crab respiration accounted for only $8 \%$ of the reduction). The crab effects were sufficient to determine whether, for a tide of a particular tide elevation, the marsh functioned as a carbon source or sink. When crabs were absent, the marsh functioned as a carbon sink at all except the very highest tides that, in turn, accounted for only $3 \%$ of all tides inundating the marsh. When crabs were present, the marsh functioned as a carbon source at $87 \%$, and all except the very lowest tides.
\end{abstract}

\section{INTRODUCTION}

Crabs are among the most abundant and conspicuous macroinvertebrates on salt marshes. Their population densities can be high, exceeding 500 ind. $\mathrm{m}^{-2}$ (Krebs \& Valiela 1978), with biomasses greater than $30 \mathrm{~g}$ dry wt $\mathrm{m}^{-2}$ (Ringold 1979). Their distributions within salt marshes can vary considerably, with highest densities usually observed on the creek banks and in the tall and medium Spartina regions (Wolf et al. 1975. Cammen et al. 1980). When a marsh is inhabited by more than 1 species, the different species may exhibit vertical patterns of zonation (Teal 1958). The distributions of the species depend on their physiological tolerance to environmental gradients (Teal 1958), and their ability to burrow in different sediment types vari-

\footnotetext{
- Present address: Graduate School of Oceanography, The University of Rhode Island, Narragansett, Rhode Island 02882-1197, USA
}

ously compacted by macrophyte roots (Ringold 1979, Bertness \& Miller 1984).

Salt marsh crabs are highly motile, burrow and deposit feed. Their burrows increase the surface area of marshes (Katz 1980), increase soil drainage and oxygen levels (Valiela et al. 1978, Montague 1982), and enhance the production of marsh macrophytes (Bertness 1985). Their burrows can also increase the abundance of meiofauna on marshes through passive deposition (DePatra \& Levin 1989) or the creation of suitable microenvironments (Bell et al. 1978). The crabs themselves consume $25 \%$ and assimilate $2.5 \%$ of the macrophyte net production of marshes (Cammen et al. 1980). Their deposit feeding can also significantly affect the taxonomic composition and production of epibenthic microbiota (Foreman 1985) and meiofauna (Hoffman et al. 1984), and increase the level of oxygenation of the surface sediments (Hoffman et al. 1984). Their burrowing and feeding activities increase the rates of sediment (and presumably nutrient) turnover within these systems (Katz 1980). 
One neglected and potentially important impact of the crabs is their influence on material fluxes across the surface of marshes. Concentrations of organic carbon (Agosta 1985) and dissolved nutrients (Yelverton \& Hackney 1986) are orders of magnitude higher in the sediments of these systems than in the inundating water. For other macrofauna, bioturbation has been shown to influence nutrient fluxes from submerged freshwater (Graneli 1979, Matishoff et al. 1985) and subtidal marine (Kristensen 1984a, b, Kristensen et al. 1985, Yamada \& Kayama 1987) sediments, but the equivalent data are not available for salt marsh crabs.

The purpose of the present study was to quantify the effects of crabs on fluxes of organic carbon across the surface of a salt marsh on the southeast coast of southern Africa. Emphasis was placed on the fluxes of total, dissolved and particulate organic carbon, because these are the fractions las opposed to the gaseous forms) potentially available for export and biological utilization in the adjoining estuary. The study is part of a larger investigation of the fluxes of organic carbon (Taylor unpubl.) and nutrients (Taylor 1992) between the marsh and estuary.

\section{STUDY SITE}

The marsh is located in the middle reaches $\left(33^{\circ} 40^{\prime}\right.$ $37^{\prime \prime} \mathrm{S}, 26^{\circ} 38^{\prime} 46^{\prime \prime} \mathrm{E}$ ) of the Kariega estuary, and details of the marsh and estuary are provided in. Taylor (1988), and Allanson \& Read (1987), respectively. The marsh has an area of 4.2 ha, $80 \%$ of which is marsh flats and $20 \%$ tidal creek. The marsh flats are covered by dense macrophyte meadows of Sarcocornia perennis (Mill.) A. J. Scott, Chenolea diffusa Thunb. and Spartina maritima (Curtis) Fernald. In terms of area covered, $S$. perennis is the dominant macrophyte, with single-species stands covering $70 \%$ of the marsh flats. The tidal creek has no macrophyte vegetation. The estuary is a small marine-dominated, lagoon-like system, and during the present study, salinities were $35 \%$ along its entire length. In the estuary, adjacent to the marsh, the water column is vertically well mixed. The marsh is submerged twice daily by semidiurnal (ca $12.4 \mathrm{~h}$ ) tides, and is completely drained of surface water at each low tide.

\section{MATERIALS AND METHODS}

Crab distribution. Crab densities and biomasses on the marsh were determined by using $(0.5 \times 0.5 \times 0.5 \mathrm{~m})$ quadrats randomly placed (using a compass and a table of random numbers) on the marsh. Crabs were removed from burrows within quadrats by rapidly forc- ing a knife at an angle, alongside and then into each burrow. To check the efficiency of this method, 8 quadrats were sampled as above, and then immediately excavated to $0.5 \mathrm{~m}$. The contents were then sieved (1.25 $\mathrm{mm}$ mesh size) to remove unsampled crabs. The mean percentage recovery ( \pm S.D.) using the abbreviated method was $78 \pm 9 \%$ for Sesarma catenata and $95 \pm 4 \%$ for Cleistostoma edwardsii, which was considered adequate for the present purpose. Crab ashfree dry weight (AFDW) was determined as loss of dry weight on ignition at $495^{\circ} \mathrm{C}$ for $5 \mathrm{~h}$. Loss of inorganic crab weight due to carbonate combustion, and loss as $\mathrm{CO}_{2}$, was checked by parallel ignition of 'Analar' $\mathrm{CaCO}_{3}$ samples: on no occasion was correction for this potential source of error necessary.

Organic carbon fluxes. Two experiments were conducted, each employing 6 replicate mesocosms. Details of the mesocosms and tidal-simulation system are provided in Taylor (1992). The first experiment involved mesocosms of the marsh flats, and the second, mesocosms of the tidal creek. Separate experiments were conducted for the 2 regions, because for this marsh they are well differentiated with unique sediment characteristics, and plant and crab communities (Taylor 1988). In each experiment, 3 mesocosms were incubated with crabs of the species dominant in that region, and 3 without. The field surveys were used determine the number and size of crabs to be added to each mesocosm.

The mesocosms were intact $0.3 \times 0.3 \times 0.1 \mathrm{~m}$ blocks of marsh surface collected with associated plants and macrofauna. The blocks were collected prior to each experiment from regions of the marsh known to support mean densities of the respective crab species. The blocks and the crabs added to the mesocosms, were collected during spring lunar-tidal phases, to match flooding in the laboratory with that in the field; the marsh is flooded most frequently and extensively during spring lunar-tidal phases, and frequently remains completely exposed during neap tides (Taylor 1988). The matching of the laboratory and field tides also served to minimize possible variability arising from endogenous, tidally linked, crab activity rhythms (Williams et al. 1985).

Crabs collected with the marsh blocks were carefully removed (using forceps) from all the mesocosms immediately the blocks were returned to the laboratory. Removal was carried out under infrared lights not visible to crabs to minimize disturbance of the marsh surface. After all the crabs had been removed, 5 Sesarma catenata crabs, weighing $0.20 \mathrm{~g}$ AFDW each, were added to each of the 3 marsh flats mesocosms designated to receive crabs. The equivalent tidal creek mesocosms each received 35 Cleistostoma edwardsii crabs, with an average individual weight of $0.01 \mathrm{~g}$ AFDW. 
The stocking values were the mean numbers and mean individual biomasses determined for the 2 regions from the field surveys. The crabs were allocated to alternate rather than random mesocosms, to ensure the with-and without-crab mesocosms were equally subjected to possible microgradients within the constant environment room.

For $2 \mathrm{~d}$ immediately following the crab additions, all mesocosms were subjected to 4 semidiurnal $(12.4 \mathrm{~h})$ tides, during which fluxes were not measured. The purpose of these tides were to flush the mesocosms of materials mobilized during block collection, and allow the added crabs to settle. The marsh flats mesocosms were then subjected to 9 semidiurnal $(12.5 \mathrm{~h})$ tides, and the tidal creek mesocosms to 15 , these being the average numbers of field tides inundating the respective regions during $14 \mathrm{~d}$ semilunar (neap-springneap) tidal cycles (Taylor 1988).

The water used to inundate the mesocosms was collected from mid-channel in the estuary adjacent to the marsh. The water was collected at high tide, to ensure that it would be typical of that normally inundating the marsh. The water was stored in the dark, at $5^{\circ} \mathrm{C}$ until use, a period always less than $72 \mathrm{~h}$. During each tide, the marsh flats and tidal creek mesocosms were inundated for 125 and $200 \mathrm{~min}$, respectively, to match the mean duration of inundation of the 2 regions in the field (Taylor 1988). These characteristics were determined from topographic surveys of the marsh, surveys of the areal inundation of the marsh at different elevation tides, and 12 mo water level records at the junction of the marsh and estuary (Taylor 1988). The horizontal water flow over the marsh that occurs during tides in the field was not simulated in the mesocosms.

The mesocosms were arranged below sodium and halogen light banks. Incident photosynthetically active radiation at the sediment surface was $92 \pm 4.3$ (SD) $\mu E \mathrm{~m}^{-2} \mathrm{~s}^{-1}(\mathrm{n}=15)$, slightly lower than that known to cause light saturation of benthic microalgal photosynthesis (Rasmussen 1983). Temperatures at the marsh surface in the mesocosms were maintained at $23 \pm$ $0.9^{\circ} \mathrm{C}$, which corresponds with the summer mean weekly temperature $5 \mathrm{~cm}$ above the marsh surface in the field (Taylor 1988). The mesocosms were exposed to $10 \mathrm{~h}$ dark : $14 \mathrm{~h}$ light photoperiod, determined from published tables of sunrise and sunset (South African Tide Tables 1987).

The mesocosms were inundated with water collected at high tide at the junction of the marsh and estuary. The water was collected within $36 \mathrm{~h}$ of use, and stored in the dark at $5^{\circ} \mathrm{C}$. Flow into the mesocosms was regulated at $0.301 \mathrm{~min}^{-1}$ using Gapmeter Type GT flow meters. The inundating water was filtered through $100 \mu \mathrm{m}$ filters prior to flooding. After each tide, water from each mesocosm was drained into an acid- cleaned, darkened, ice-enclosed glass bottle. Duplicate water samples for analysis were collected from the inflowing water during inundation, and from the outflowing water in each glass bottle after complete drainage of the mesocosms. One of the duplicate influent and effluent samples were filtered through ashed, prerinsed Whatman GF/F filter paper, and the filtrate used for determining concentrations of dissolved organic carbon. The unfiltered samples were used to estimate total organic carbon (TOC). Concentrations of particulate organic carbon (POC) were determined by difference. After filtration, the water samples were stored at $-15^{\circ} \mathrm{C}$, in the dark until analysis. Concentrations were determined using a Beckman 915B Total Organic Carbon Analyzer, after removal of inorganic carbon by acid sparging. Precision of the analytical technique, as applied, and expressed as percentage coefficient of variation, was between 3 and $6 \%$ at DOC concentrations of 3 to $10 \mathrm{mg} \mathrm{Cl}^{-1}(\mathrm{n}=9)$.

For each chemical component, areal net fluxes per tide, $F_{\mathrm{m}}\left(\mathrm{mg} \mathrm{m}^{-2}\right.$ tide $\left.^{-1}\right)$, were computed for each mesocosm as follows:

$$
F_{\mathrm{m}}=(O-I) \mathrm{V} / \mathrm{A}
$$

where $I=$ concentration in influent water $\left(\mathrm{mg} \mathrm{l}^{-1}\right)$; $O=$ concentration in effluent water $\left(\mathrm{mg} \mathrm{l}^{-1}\right) ; V=$ volume of water drained from mesocosm (l); and $A=$ area of top of sediment block $\left(\mathrm{m}^{2}\right)$. This computation assumes the volume of water leaving each mesocosm is the same as that entering. This was checked, and retention by the marsh blocks found to be between 2 and $8 \%$ of influent volume

Crab respiration. Weight-specific respiration rates of Sesarma catenata and Cleistostoma edwardsii, as oxygen uptake per unit AFDW, were determined using a Gilson Single Valve Differential Respirometer. The crabs used for the respiration measurements were those used earlier in the mesocosm experiments, to allow direct comparison of the carbon losses via respiration and bioturbation. Prior to the respiration measurements, the crabs were equilibriated in prefiltered (Whatman GF/F), autoclaved estuarine water at room temperature for $2 \mathrm{~h}$, to ensure gut clearance. Crabs were then placed in $50 \mathrm{ml}$ experimental flasks, which each contained $10 \mathrm{ml}$ prefiltered autoclaved estuarine water. The central well in each flask contained $500 \mathrm{~mm}^{2}$ fluted Whatman GF/C filter paper soaked in $1.5 \mathrm{ml} 10 \% \mathrm{KOH}$, which served as a $\mathrm{CO}_{2}$ trap. Control treatments were as for experimental treatments, except the flasks were incubated without crabs. Experimental and control flasks were allowed to equilibrate for $15 \mathrm{~min}$ before valve closure, and changes in gas volume then monitored for $3 \mathrm{~h}$. Flasks were incubated at $23^{\circ} \mathrm{C}$, the same temperature at which the mesocosms were incubated. 
Respiratory oxygen consumption rates were converted to carbon equivalents assuming respiratory quotients $(R Q)$ of 0.71 and 1.0. Since $R Q$ values vary depending on substrate respired $(0.71$ for lipid, 0.80 for protein, and 1.0 for carbohydrate; Lampert 1984), and the metabolic substrates of Sesarma catenata and Cleistostoma edwardsii on the marsh were not known, respiratory rates were calculated using both the minimum and maximum RQ values.

Crab excretion. Weight-specific rates of excretion of DOC were measured using crabs removed from the mesocosms. Crabs were rinsed and gently scrubbed with a soft brush to remove dissolved and attached particulate material, and then equilibriated for $2 \mathrm{~h}$ in pre-filtered (Whatman $G F / F$ ), autoclaved estuarine water, at room temperature. The crabs were then incubated in $50 \mathrm{ml}$ prefiltered, autoclaved estuarine water for $4 \mathrm{~h}$, at $23^{\circ} \mathrm{C}$. Water samples for analysis were collected before and after incubation, filtered and analyzed as above. Replicates in which crabs had produced fecal pellets were discarded. Control measurements were conducted in duplicate, using containers incubated with estuarine water, without crabs.

Epibenthic respiration and photosynthesis. Epibenthic respiration and photosynthetic rates were determined using $2.0 \mathrm{ml}$ surface sediment samples incubated in a Gilson Respirometer (Umbreit et al. 1972). At the start and end of each mesocosm experiment, six $3 \mathrm{~mm}$ deep sediment samples were collected from the marsh surface using a $100 \mathrm{~mm}$ diameter core. At the end of the mesocosm experiments, sediment samples were collected from random positions within each mesocosm, and pooled. Sediment samples could not be collected from the mesocosms prior to the experiments without causing significant disturbance of the systems. Therefore, before each experiment, the sediments were collected in the field immediately adjacent to the sites of collection of the mesocosm blocks. During incubation in the Gilson Respirometer, the sediment samples in the flasks were shaken horizontally at 65 traverses $\mathrm{min}^{-1}$ (amplitude of each traverse $=275 \mathrm{~mm}$ ). The measured rates therefore represent potential values.

To measure the potential rates of sediment (or epibenthic) respiration, the flasks were incubated in the dark at $22.0 \pm 1.0^{\circ} \mathrm{C}$, equivalent to the summer temperature employed for the mesocosms. Incubation lasted $11 \mathrm{~h}$. Measurements were not made for the first $3 \mathrm{~h}$, during which oxygen uptake rates were high, and largely non-biological. For the next 4 h, readings representing total oxygen uptake were recorded hourly. Mercuric chloride $(0.1 \mathrm{ml} 1 \%)$ was then added to each flask as a metabolic inhibitor, and after 15 min equilibration, volume changes equivalent to nonbiological uptake were recorded for a further $4 \mathrm{~h}$. Rates of biological oxygen uptake were determined by difference, and assumed to measure community respiration of the surface sediments. This assumption was considered valid, because at the $E_{h}$ values ( $>+350 \mathrm{mV}$ ) exhibited by the marsh surface sediments (Taylor 1988), aerobic respiration with oxygen as the major terminal electron acceptor, is the dominant respiratory pathway (Sorenson et al. 1979).

Rates of epibenthic net photosynthesis (NP) were determined as for community respiration, except the flasks were incubated in the light $\left(90 \mu \mathrm{E} \mathrm{m}^{-2} \mathrm{~s}^{-1}\right)$ for $8 \mathrm{~h}$, and the oxygen changes were not partitioned into biological and nonbiological components using mercuric chloride. Rates of gross photosynthesis (GP) were determined by adding estimates of dark oxygen uptake to light oxygen production measured in parallel treatments. The oxygen exchange rates were converted to carbon equivalents using a factor of 0.32 . Chlorophyll a, corrected for phaeophytin degradation products, was determined according to Sartory (1985).

\section{RESULTS}

Seven species of crabs were observed on the marsh, but in terms of numbers and biomass 2 species dominated, the grapsoid Sesarma catenata Ortm. and the ocypodoid Cleistostoma edwardsii McLeay. The vertical distributions of the 2 species differed, with $C$. edwardsii having maximum densities in the tidal creek, between 0.9 and $1.1 \mathrm{~m}$ above mean sea level (MSL), and $S$. catenata in the marsh flats, between 1.2 and $1.3 \mathrm{~m}$ above MSL (Table 1). For all quadrats in which the species were observed, C. edwardsii showed mean densities (386 \pm 127 ind. $\mathrm{m}^{-2}, \pm 95 \% \mathrm{CL}$ ) an order of magnitude higher than S. catenata ( $47 \pm 8$ ind. $\mathrm{m}^{-2}, \pm 95 \% \mathrm{CL}$ ), but $C$. edwardsii individuals were an order of magnitude smaller; 0.01 vs $0.19 \mathrm{~g}$ AFDW ind. $^{-1}$. The mean areal biomass of $S$. catenata $(8.7 \pm$ $\left.1.0 \mathrm{~g} \mathrm{AFDW} \mathrm{m}^{-2}\right)$ exceeded $C$. edwardsii $(3.8 \pm 0.6 \mathrm{~g}$ AFDW $\mathrm{m}^{-2}$ ) by a factor of 2.3 .

In both regions, whether crabs were present or not, the mean net fluxes of TOC (calculated for the 3 replicates and all tides combined) were directed from the marsh surface to the water column, mainly as DOC (Fig. 1, Table 2). (Positive flux values indicate net loss from the marsh surface to the water column, and negative values, net uptake). The mean fluxes of all three organic carbon fractions were greater from the tidal creek than from the marsh flats. In the tidal creek, Cleistostoma edwardsii significantly enhanced the mean net fluxes of all 3 organic carbon fractions. The fluxes of TOC were enhanced by $224 \mathrm{mg} \mathrm{C} \mathrm{m} \mathrm{m}^{-2}$ tide $^{-1}$ (or $60.5 \mathrm{mg} \mathrm{C} \mathrm{m}^{-2} \mathrm{~h}^{-1}$ ), and most (66\%) of this was in 
Table 1 Sesarma catenata and Cleistostoma edwardsii. Densities and ash-free dry weights (AFDW) of crabs at different elevations on the marsh. MSL: mean sea level

\begin{tabular}{|c|c|c|c|c|}
\hline \multirow{2}{*}{$\begin{array}{c}\text { Elevation } \\
\text { (m above MSL) }\end{array}$} & \multicolumn{2}{|c|}{ S. catenata } & \multicolumn{2}{|c|}{ C. edwardsii } \\
\hline & $\begin{array}{l}\text { Density } \\
\text { (ind. } \mathrm{m}^{-2} \text { ) }\end{array}$ & $\begin{array}{c}\text { Biomass } \\
\left(\mathrm{g} \text { AFDW } \mathrm{m}^{-2} \text { ) }\right.\end{array}$ & $\begin{array}{l}\text { Density } \\
\text { (ind. } \mathrm{m}^{-2} \text { ) }\end{array}$ & $\begin{array}{c}\text { Biomass } \\
\text { (g AFDW m }{ }^{-2} \text { ) }\end{array}$ \\
\hline $0.81-0.90$ & 0 & 0 & $9 \pm 22$ & $1.06 \pm 3.73$ \\
\hline $0.91-1.00$ & $3 \pm 6$ & $0.1 \pm 0.2$ & $535 \pm 43$ & $5.16 \pm 3.80$ \\
\hline $1.01-1.10$ & $32 \pm 12$ & $7.8 \pm 8.5$ & $560 \pm 22$ & $5.41 \pm 1.91$ \\
\hline $1.11-1.20$ & $46 \pm 29$ & $8.5 \pm 10.1$ & $193 \pm 33$ & $1.67 \pm 2.8$ \\
\hline $1.21-1.30$ & $92 \pm 27$ & $14.1 \pm 13$ & 0 & 0 \\
\hline $1.31-1.40$ & $23 \pm 14$ & $6.3 \pm 7.3$ & 0 & 0 \\
\hline $\begin{array}{c}\text { Mean }+95 \% \mathrm{CL} \\
\text { (n) }\end{array}$ & $\begin{array}{r}47 \pm 8 \\
(38)\end{array}$ & $\begin{array}{c}8.7 \pm 1.0 \\
(38)\end{array}$ & $\begin{array}{c}386 \pm 127 \\
(72)\end{array}$ & $\begin{array}{c}3.8 \pm 0.6 \\
(72)\end{array}$ \\
\hline
\end{tabular}

the particulate form. In the marsh flats, the mean fluxes were higher from the mesocosms with crabs than from those without, but the differences between the with-and without-crab mesocosms were not statistically significant.

The weight-specific rates of DOC excretion were $146 \pm 76$ and $328 \pm 178 \times 10^{-3}$ mg $\mathrm{C} \mathrm{g}^{-1}$ AFDW h${ }^{-1}$ for Sesarma catenata and Cleistostoma edwardsii, respectively. With biomasses of $S$. catenata and $C$. edwardsii being 11.1 and $3.9 \mathrm{~g} \mathrm{AFDW} \mathrm{m}^{-2}$, the areal rates of crab excretion of DOC were $1.6 \mathrm{mg} \mathrm{C} \mathrm{m} \mathrm{m}^{-2} \mathrm{~h}^{-1}$ in the marsh flats and $1.3 \mathrm{mg} \mathrm{C} \mathrm{m}{ }^{-2} \mathrm{~h}^{-1}$ in the tidal creek. For both species, the carbon losses via respiration were greater than the excretory losses. Assuming a RQ of 0.71, the areal rates of respiration by $S$. catenata and $C$. edwardsii were 2.5 and $2.0 \mathrm{mg} \mathrm{C} \mathrm{m}^{-2} \mathrm{~h}^{-1}$. respectively (Table 3 ). Assuming a $\mathrm{RQ}$ of 1.0 , the equivalent values were 3.6 and $2.8 \mathrm{mg} \mathrm{C} \mathrm{m}^{-2} \mathrm{~h}^{-1}$.

In the marsh flats, Sesarma catenata decreased the potential rates of epibenthic NP and GP, but not respiration (Table 4). Cleistostoma edwardsii in the tidal creek had no significant impact on epibenthic NP, GP or R. Both species decreased the chlorophyll a contents of the surface sediments (presumably through grazing), and increased rates of specific GP (or GP per unit chlorophyll). S. catenata lowered the rates of gross photosynthesis relative to respiration (GP:R), but $C$. edwardsii increased this ratio, suggesting differential consumption of autotrophic microalgae by $S$. catenata, and heterotrophic bacteria or meiofauna by $C$. edwardsii.

The relative impacts of the 2 species on the different processes regulating carbon fluxes at the marsh sur-

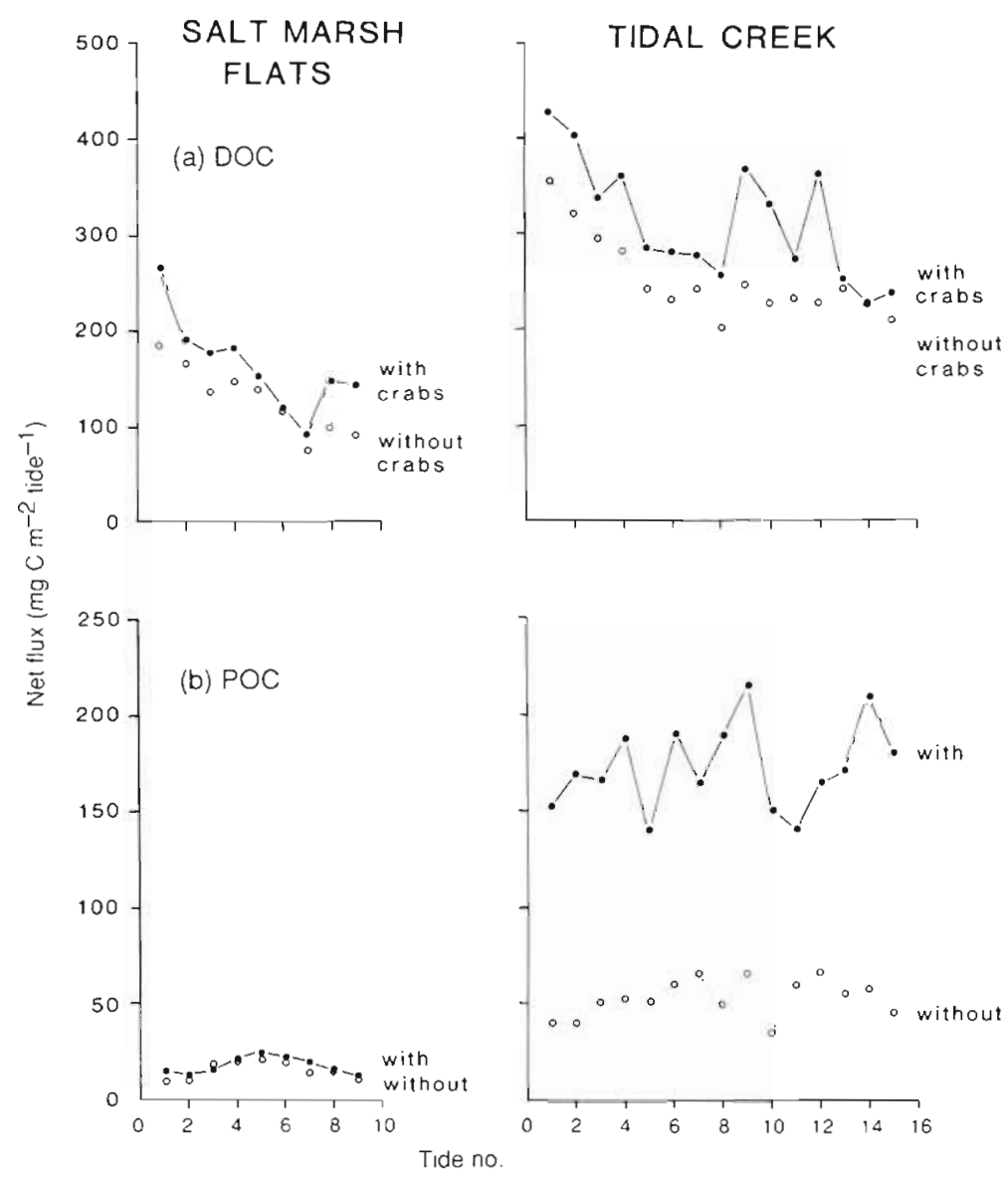

Fig. 1 Sesarma catenata and Cleistostoma edwardsii. Tidal net fluxes of DOC and POC from mesocosms of the marsh flats (with and without $S$. catenata) and tidal creek regions (with and without $C$. edwardsii), over a simulated, average semilunar tidal cycle (equivalent to 9 and 15 semidiurnal tides in the respective regions). Each point represents the mean $(n=3)$ net flux per semidiurnal tide, for either the with-or without-crab treatments face are summarized in Table 5. In both regions (and especially in the tidal creek), the crab-enhanced fluxes of TOC were large compared to the carbon losses via crab excretion. The remainder of the TOC fluxes were a result of crab bioturbation. In the tidal 


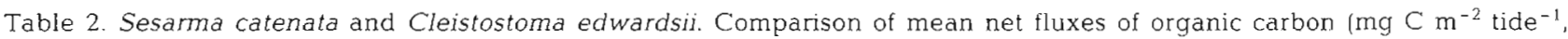
$\pm 95 \% \mathrm{CL}$ ) in the presence and absence of crabs in mesocosms of the marsh flats (with and without S. catenata) and tidal creek (with and without $C$. edwardsii). Each flux value represents the mean fluxes from 3 replicate mesocosms, for all tides combined. No. of tides in parentheses

\begin{tabular}{|c|c|c|c|c|}
\hline \multirow[t]{3}{*}{ Component } & \multicolumn{4}{|c|}{ Mean net flux } \\
\hline & \multicolumn{2}{|c|}{ Marsh flats } & \multicolumn{2}{|c|}{ Tidal creek } \\
\hline & With crabs & Without crabs & With crabs & Without crabs \\
\hline TOC & $\begin{array}{c}+188 \pm 50.7 \\
(26)\end{array}$ & $\begin{array}{c}+152 \pm 33.4 \\
(26)\end{array}$ & $\begin{array}{c}+590 \pm 136 \\
(44)\end{array}$ & $\begin{array}{c}+366 \pm 69.5 \\
(44)\end{array}$ \\
\hline DOC & $\begin{array}{c}+169 \pm 25.0 \\
(26)\end{array}$ & $\begin{array}{c}+135 \pm 16.6 \\
(26)\end{array}$ & $\begin{array}{c}+381 \pm 29.3 \\
(44)\end{array}$ & $\begin{array}{c}+304 \pm 24.0 \\
(44)\end{array}$ \\
\hline $\mathrm{POC}$ & $\begin{array}{c}+19 \pm 5.0 \\
(26)\end{array}$ & $\begin{array}{c}+17 \pm 4.6 \\
(26)\end{array}$ & $\begin{array}{c}+209 \pm 33.4 \\
(44)\end{array}$ & $\begin{array}{c}+62 \pm 13.0 \\
(44)\end{array}$ \\
\hline
\end{tabular}

Table 3. Sesarma catenata and Cleistostama edwardsii. Mean ( $\$ 95 \% \mathrm{CL}$ ) mass-specific respiration rates expressed in oxygen and carbon terms. $\mathrm{n}=15$ and 19 for $S$, catenata and $C$. edwardsii, respectively

\begin{tabular}{|c|c|c|c|c|}
\hline \multirow[t]{2}{*}{ Species } & \multirow[t]{2}{*}{$\begin{array}{l}\text { Mean AFDW } \\
\text { per individual } \\
\qquad(\mathrm{g})\end{array}$} & \multirow[t]{2}{*}{$\begin{array}{l}\mathrm{O}_{2} \text { consumption } \\
\left(\mu \mathrm{g} \mathrm{O} \mathrm{O}^{-1} \mathrm{~h}^{-1}\right)\end{array}$} & \multicolumn{2}{|c|}{$\begin{array}{c}\mathrm{CO}_{2} \text { equivalence } \\
\left(\mu \mathrm{g} \mathrm{C} \mathrm{g}^{-1} \mathrm{~h}^{-1}\right) \\
\text { assuming: }\end{array}$} \\
\hline & & & $\mathrm{RQ}=0.71$ & $\mathrm{RQ}=1.0$ \\
\hline S. catenata & $0.09 \pm 0.04$ & $611 \pm 27$ & $229 \pm 10$ & $325 \pm 14$ \\
\hline C. edwardsii & $0.016 \pm 0.004$ & $1370 \pm 38$ & $514 \pm 14$ & $731 \pm 20$ \\
\hline
\end{tabular}

creek, bioturbation by Cleistostoma edwardsii accounted for $99 \%$ of the hourly and $94 \%$ of the daily TOC fluxes attributable to the crabs. In the marsh flats, where Sesarma catenata had less impact on the fluxes of $\mathrm{TOC}$, the equivalent values were 88 and $47 \%$. (Bioturbation is used here to describe sediment disturbance, breakup and resuspension of feces,

Table 4. Sesarma catenata and Cleistostoma edwardsii. Effects of crabs on mean $(+95 \% \mathrm{CL})$ rates of respiration $(\mathrm{R})$, net (NP) and gross (GP) photosynthesis, specific rates of GP, GP: $R$ ratios, and chlorophyll a contents of surface sediments of the marsh flats (with and without S. catenata) and tidal creek (with and without C. edwardsii) mesocosms. No. of sediment sample measurements in parenthe-

\begin{tabular}{|c|c|c|c|c|}
\hline \multirow[t]{2}{*}{ Variable } & \multicolumn{2}{|c|}{ Marsh flats } & \multicolumn{2}{|c|}{ Tidal creek } \\
\hline & $\begin{array}{l}\text { With } \\
\text { crabs }\end{array}$ & $\begin{array}{l}\text { Without } \\
\text { crabs }\end{array}$ & $\begin{array}{l}\text { With } \\
\text { crabs }\end{array}$ & $\begin{array}{l}\text { Without } \\
\text { crabs }\end{array}$ \\
\hline $\begin{array}{l}N P \\
\left(m g C m^{-2} h^{-1}\right)\end{array}$ & $\begin{array}{c}-9+6 \\
(7)\end{array}$ & $\begin{array}{c}16+7 \\
(7)\end{array}$ & $\begin{array}{c}31+10 \\
(7)\end{array}$ & $\begin{array}{c}35+14 \\
(6)\end{array}$ \\
\hline $\begin{array}{l}\mathrm{GP} \\
\left(\mathrm{mg} \mathrm{C} \mathrm{m} \mathrm{m}^{-2} \mathrm{~h}^{-1}\right)\end{array}$ & $\begin{array}{c}36+11 \\
(7)\end{array}$ & $\begin{array}{c}65+18 \\
(7)\end{array}$ & $\begin{array}{c}45+12 \\
(7)\end{array}$ & $\begin{array}{c}56+14 \\
(6)\end{array}$ \\
\hline $\begin{array}{l}\mathrm{R} \\
\left(\mathrm{mgC} \mathrm{m}^{-2} \mathrm{~h}^{-1}\right)\end{array}$ & $\begin{array}{c}45+14 \\
(7)\end{array}$ & $\begin{array}{c}49+17 \\
(7)\end{array}$ & $\begin{array}{c}14+4 \\
(7)\end{array}$ & $\begin{array}{c}21+9 \\
(6)\end{array}$ \\
\hline $\begin{array}{l}\text { Chlorophyll a } \\
\left(\mathrm{mg} \mathrm{m}^{-2}\right)\end{array}$ & $\begin{array}{c}31+4 \\
(5)\end{array}$ & $\begin{array}{c}82+12 \\
(5)\end{array}$ & $\begin{array}{l}54+8 \\
(5)\end{array}$ & $\begin{array}{c}82+25 \\
\text { (6) }\end{array}$ \\
\hline $\begin{array}{l}\text { Specific GP } \\
\left(\mathrm{mg} \mathrm{C} \mathrm{mg} \mathrm{chl} a^{-1} \mathrm{~h}^{-1}\right)\end{array}$ & 1.2 & 0.8 & 0.8 & 0.7 \\
\hline GP:R & 0.8 & 1.3 & 3.2 & 2.7 \\
\hline
\end{tabular}

and damage to macrophytes and microbiota during crab feeding, burrowing, and locomotion.) In both regions, the carbon losses via crab respiration were small compared to the effects of the crabs on rates of epibenthic NP. In the marsh flats, where epibenthic NP was decreased most by the crabs, respiratory losses were equivalent to $16 \%$ (hourly) and $14 \%$ (daily) of the reduction in epibenthic NP (Table 5). In the tidal creek, the relative contribution of respiratory losses was greater than in the marsh flats, and equivalent to $75 \%$ (hourly) and $70 \%$ (daily) of the reduced epibenthic NP.

Table 6 summarizes the effects of the crabs on the daily carbon budgets of the 2 regions. Both species enhanced the carbon losses relative to uptake by the marsh (by $1204 \mathrm{mg} \mathrm{C}$ $\mathrm{m}^{-2} \mathrm{~d}^{-1}$ in the marsh flats and $505 \mathrm{mg}$ $\mathrm{C} \mathrm{m}^{-2} \mathrm{~d}^{-1}$ in the tidal creek), but they did so via different mechanisms. In the marsh flats, Sesarma catenata decreased community NP by $1132 \mathrm{mg} \mathrm{C}$ $m^{-2} d^{-1}$, but their effects on TOC fluxes were small and not statistically significant. In the tidal creek, Cleistostoma edwardsii enhanced the fluxes of TOC, but had no significant impact on community NP. 


\section{DISCUSSION}

On the Kariega marsh, Cleistostoma edwardsii and Sesarma catenata occupy similar vertical positions to the sand and mud fiddler crabs, Uca pugilator and $U$. pugnax respectively, on the marshes of the southeast USA (Teal 1958, Colby \& Fonseca 1984). C. edwardsii, like $U$. pugilator, occupies the coarser-grained substrata of the creek banks and the regions of the marsh flats closest to the tidal creek. $S$. catenata and $U$. pugnax occur higher up the marsh in the vegetated regions with finer, more consolidated sediments. The mean densities of $S$. catenata $\left(47\right.$ ind $\mathrm{m}^{-2}$; on the marsh, and used in the mesocosm experiments, lie in the mid-to lower range reported for $U$. pugnax $\left(0\right.$ to $>500$ ind. $\mathrm{m}^{-2}$; Table 7$)$.

For $C$. edwardsii, the mean densities $\left(390 \mathrm{~m}^{-2}\right)$ were generally higher than those reported for $U$. pugilator, in part because most previous studies employed $5 \mathrm{~mm}$ mesh compared to the $1.25 \mathrm{~mm}$ mesh used in the present study. Krebs \& Valiela (1978) compared the densities of $U$. pugnax on Great Sippewissett Marsh using 2 and $5 \mathrm{~mm}$ mesh, and noted the $5 \mathrm{~mm}$ mesh underestimated densities by almost $80 \%$.

Comparison of the flux estimates from the mesocosms with those measured between the marsh and estuary in the field (Taylor unpubl.) and between other marsh-estuarine systems, indicates the patterns ob- served in the mesocosms are realistic. On annual time scales, most marshes export DOC and POC (Nixon 1980, Dame et al. 1986), and this applied to the mesocosms of both regions over the 9 to 14 simulated tides. For the marsh flats, the mean TOC fluxes $\left(137 \mathrm{~g} \mathrm{C} \mathrm{m}^{-2}\right.$ $\mathrm{yr}^{-1}$ ) were similar to the fluxes of 100 to $200 \mathrm{~g} \mathrm{C} \mathrm{m}^{-2}$ $\mathrm{yr}^{-1}$ predicted for salt marshes by Nixon (1980). For the tidal creek, the fluxes of $430 \mathrm{~g} \mathrm{C} \mathrm{m}^{-2} \mathrm{yr}^{-1}$ were higher Based on previous field measurements of fluxes between the marsh and estuary over 42 tides, the mean annual net flux of TOC from the marsh to the estuary has been estimated to be $5 \mathrm{~g} \mathrm{C} \mathrm{m}^{-2} \mathrm{yr}^{-1}$ (Taylor un-

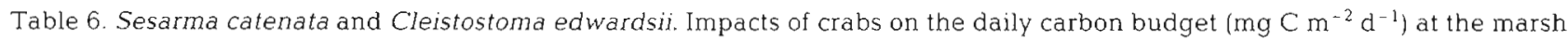
surface. Symbols not in parentheses represent direction of net flux: + values denote net loss to water column; - values net uptake by marsh surface. Effects of crabs are denoted using parenthesized symbols: $(+)$ indicates crabs enhanced the process; (-) indicates crabs reduced the rate. nd: not determined

\begin{tabular}{|c|c|c|c|c|c|c|}
\hline & \multicolumn{3}{|c|}{ Marsh flats (S. catenata) } & \multicolumn{3}{|c|}{ Tidal creek (C. edwardsii) } \\
\hline & $\begin{array}{l}\text { With } \\
\text { crabs }\end{array}$ & $\begin{array}{l}\text { Without } \\
\text { crabs }\end{array}$ & $\begin{array}{l}\text { Effect of } \\
\text { crabs }^{a}\end{array}$ & $\begin{array}{l}\text { With } \\
\text { crabs }\end{array}$ & $\begin{array}{l}\text { Without } \\
\text { crabs }\end{array}$ & $\begin{array}{l}\text { Effect of } \\
\text { crabs }^{\mathrm{a}}\end{array}$ \\
\hline TOC net flux ${ }^{b}$ & +376 & +304 & $(+) 72$ & +1180 & +723 & $(+) 448$ \\
\hline Epibenthic NPc & +660 & -396 & $(-) 264$ & -192 & -168 & $(-) 24$ \\
\hline Sarcocornia NPd & -1068 & -1068 & 0 & nd & nd & nd \\
\hline Community NPe & -332 & -1464 & $(-) 1132$ & -120 & -168 & $(-) 48$ \\
\hline Balance d"'li & +44 & -1160 & 1204 & +1060 & +555 & 505 \\
\hline \multicolumn{7}{|c|}{ Mean rates with crabs minus mean rates without } \\
\hline \multicolumn{7}{|c|}{$\begin{array}{l}{ }^{b} \text { Calculated from hourly rates, assuming } 2.1 \text { and } 3.7 \mathrm{~h} \text { inundation in the marsh flats and tidal creek regions, and both regions } \\
\text { inundated twice daily. Includes excretory losses }\end{array}$} \\
\hline \multicolumn{7}{|c|}{$\begin{array}{l}\text { Calculated from data in Table } 4 \text { assuming a } 12 \mathrm{~h} \text { light: } 12 \mathrm{~h} \text { dark regime, and subtracting dark respiration from net } \\
\text { production }\end{array}$} \\
\hline \multicolumn{7}{|c|}{ d From Christie (1981), and assumed to be the same in the presence and absence of crabs } \\
\hline \multicolumn{7}{|c|}{ Epibenthic NP plus Sarcocornia NP minus crab respiration } \\
\hline i Community NP & TOC net & & & & & \\
\hline
\end{tabular}


Table 7. Comparison of the densities of the crab populations on the Kariega Marsh with crab populations on other marshes and mud and sandflat regions in the U.S. nd: not determined

\begin{tabular}{|c|c|c|c|c|}
\hline Marsh & Species & $\begin{array}{l}\text { Crab size } \\
(>\mathrm{mm})\end{array}$ & $\begin{array}{l}\text { Density } \\
\text { (ind } \mathrm{m}^{-2} \text { ) }\end{array}$ & Source \\
\hline $\begin{array}{l}\text { Kariega Marsh, } \\
\text { South Africa }\end{array}$ & $\begin{array}{l}\text { Sesarma catenata } \\
\text { Cleistostoma edwardsii }\end{array}$ & $\begin{array}{l}1.25 \\
1.25\end{array}$ & $\begin{array}{r}47^{\mathrm{a}} \\
390^{\mathrm{d}}\end{array}$ & Present study \\
\hline Great Sippewissett, MA & Uca pugnax & $\begin{array}{l}5 \\
2\end{array}$ & $\begin{array}{l}113^{\mathrm{d}} \\
401^{\mathrm{d}}\end{array}$ & Krebs \& Valiela (1978) \\
\hline Little Sippewissett, MA & Uca pugnax & nd & $34-42^{b}$ & Katz $(1980\}$ \\
\hline Smith Cove, RI & Uca pugnax & 5 & $42-109^{\circ}$ & Bertness \& Miller (1984) \\
\hline Dutchman Creek, NC & $\begin{array}{l}\text { Uca pugnax } \\
\text { U. minax }\end{array}$ & $\begin{array}{l}2 \\
2\end{array}$ & $\begin{array}{c}18-42^{\mathrm{d}} \\
0-2^{\mathrm{d}}\end{array}$ & Cammen et al. (1984) \\
\hline Oak Island, NC & $\begin{array}{l}\text { Uca pugnax } \\
\text { U. minax }\end{array}$ & $\begin{array}{l}2 \\
2\end{array}$ & $\begin{array}{c}10-40^{d} \\
0-3^{d}\end{array}$ & \\
\hline Snow's Marsh, NC & $\begin{array}{l}\text { Uca pugnax } \\
\text { U. minax }\end{array}$ & $\begin{array}{l}2 \\
2\end{array}$ & $\begin{array}{l}6-29^{d} \\
0-5^{d}\end{array}$ & Cammen et al. (1984) \\
\hline Walden Creek, NC & $\begin{array}{l}\text { Uca pugnax } \\
\text { U. minax }\end{array}$ & $\begin{array}{l}2 \\
2\end{array}$ & $\begin{array}{r}14-45^{a} \\
0-10^{a}\end{array}$ & Cammen et al. (1984) \\
\hline Shackleford Banks, NC & Uca pugilator & 5 & $34-65^{a}$ & Colby \& Fonseca $(1984)$ \\
\hline Bell Creek, NC & $\begin{array}{l}\text { Uca pugnax } \\
\text { U. minax }\end{array}$ & $\begin{array}{l}1 \\
1\end{array}$ & $\begin{array}{c}12-42^{\mathrm{a}} \\
0-6^{\mathrm{a}}\end{array}$ & Ringold (1979) \\
\hline Sapelo Island, GA & $\begin{array}{l}\text { Uca pugnax } \\
\text { U. pugilator } \\
\text { Sesarma reticulatum } \\
\text { S. cinereum }\end{array}$ & $\begin{array}{l}\text { nd } \\
\text { nd } \\
\text { nd } \\
\text { nd }\end{array}$ & $\begin{array}{l}0-61^{c} \\
0-52^{c} \\
0-30^{c} \\
0-2^{c}\end{array}$ & Teal (1958) \\
\hline Reynold's Marsh, GA & Uca pugnax & 0.5 & $27-196^{d}$ & Wolf et al. (1975) \\
\hline Matanzas Inlet, FL & Uca pugnax & nd & $156-205^{c}$ & Genoni (1991) \\
\hline Oak Creek, CA & $\begin{array}{l}\text { Pachygrapsus crassipes } \\
\text { Hemigrapsus oregonensis }\end{array}$ & $\begin{array}{l}\text { nd } \\
\text { nd }\end{array}$ & $\begin{array}{l}40^{c} \\
90^{c}\end{array}$ & Willason (1981) \\
\hline Pirhana Creek, CA & $\begin{array}{l}\text { Pachygrapsus crassipes } \\
\text { Hemigrapsus oregonensis }\end{array}$ & $\begin{array}{l}\text { nd } \\
\text { nd }\end{array}$ & $\begin{array}{r}4^{c} \\
60^{c}\end{array}$ & Willason (1981) \\
\hline \multicolumn{5}{|c|}{$\begin{array}{l}\text { a Determined by sediment sieving } \\
{ }^{b} \text { Determined from burrow densities } \\
{ }^{c} \text { Crabs removed by visual selection rather than sieving }\end{array}$} \\
\hline
\end{tabular}

publ.). This is small compared to the fluxes observed from the mesocosms of both regions, and several factors probably account for this.

In the present experiments, the mesocosms of the 2 regions were incubated separately, whereas in the field water flows between the 2 regions resulting in the recycling and retention of material within the marsh (Welsh 1980). Therefore on a flood tide, some fraction of the POC resuspended in the tidal creek (by bioturbation and other processes) would be deposited on the higher, densely vegetated marsh flats (Gleason et al. 1979), decreasing the POC loss from the marsh. Also, in the field the creek sediments at the mouth of the marsh are inhabited by dense populations of filterfeeding bivalves (Solen cylindraceus) and anomuran crustaceans (Upogebia africana) (Hodgson 1987), which retain particulate material leaving the marsh (Dame et al. 1984, Chrzanowski et al. 1986). Because the marsh blocks were only $0.3 \mathrm{~m}$ deep, and were collected in the middle of the marsh (where these filter feeders were absent), the mesocosm flux values are probably overestimates. Some proportion of the organic carbon lost from the mesocosms was probably also caused by marsh disturbance during block collection and crab removal. Considerable care was taken to minimize this disturbance, but some disruption (and presumably release of organic carbon) was unavoidable.

The mesocosm experiments demonstrated that both species enhanced the losses of carbon relative to uptake by the marsh, one by increasing the fluxes of organic carbon, and the other by reducing epibenthic NP (Table 6). The reasons for the different effects of the 2 species are not known for certain. Data are not available on the sediment organic carbon pools in the 2 regions, or on the feeding and burrowing behavior of the 
2 species. The sediments are, however, coarser grained, and presumably less consolidated in the tidal creek than the marsh flats, and this may account for the greater bioturbation effects of Cleistostoma edwardsii in the tidal creek. The mud (subsieve $<63 \mu \mathrm{m}$ ) contents of the tidal creek sediments were $<300 \mathrm{mg} \mathrm{g}^{-1}$ dry wt, compared to $>900 \mathrm{mg} \mathrm{g}^{-1}$ dry wt in the marsh flats (Taylor 1988). Cross-incubation of the 2 species in mesocosms of the 2 regions would have allowed the contributions of crab behavior and the properties of the marsh regions to be differentiated, but these experiments still need to be conducted.

Potentially, the crab effects on the carbon budgets of salt marshes can be partitioned into the effects of the crabs themselves (e.g. Cammen et al. 1980, Hoffman et al. 1984, Foreman 1985) and the effects of their burrows (e.g. Katz 1980, Montague 1982). Because both the with-and without-crab mesocosms contained preexisting burrows, the present experiments quantified the impacts of the crabs. The experiments were conducted on a time scale of days to minimize laboratory enclosure effects, and therefore did not address the longer-term effects of the crabs such as their seasonal carbon accumulation in biomass, or their carbon loss through gamete release or detachment of exuviae. The crab surveys and mesocosm experiments were also conducted in summer or under simulated summer conditions, and the effects of the crabs at other times of the year may have been different. A laboratory mesocosm approach was adopted in preference to field exclosure experiments for several reasons. The mesocosms al- lowed total exclusion of the crabs, whereas in the field deep burrows might have provided crabs with access to without-crab controls. Unless the field exclosures had been far apart, which would have increased substrate variability and made detection of the crab effects more difficult, materials released or mobilized by the crabs (from both the with-crab exclosures and the general marsh surface) might also have been transfered (through tidal flow) to the controls. The laboratory approach also allowed partial control of the ambient environment.

Using the flux and epibenthic production data from the mesocosms, and the data from a survey of the marsh area inundated by different elevation tides (Taylor 1988), it has been possible to quantify the effects of the crabs on the exchanges of carbon $\mathrm{m}^{-2}$, averaged for the entire marsh (Table 8). The marsh is inundated by tides ranging in maximum elevation from 0.7 to $>1.8 \mathrm{~m}$ above MSL, with the mean maximum tide elevation being $1.1 \mathrm{~m}$ above MSL (Taylor 1988). When tides are too low to inundate the marsh (<0.7 $\mathrm{m}$ above MSL), the marsh apparently functions as a carbon sink, whether crabs are present or not. However, for higher tides the direction of the net exchanges of carbon vary depending interactively on tide elevation and the presence or absence of crabs. If crabs are absent, the marsh functions as a carbon sink at all except the highest ( $>1.6 \mathrm{~m}$ above MSL) tides, which are in turn relatively rare. Water levels reach or exceed this elevation at only $3 \%$ of tides (Taylor 1988). When crabs are present, the marsh serves as a carbon source

Table 8. Effects of crabs on carbon fluxes $\left(\mathrm{m}^{-2}\right)$ averaged over the entire marsh for tides of different elevations. MSL: mean sea level; NP: net community production. Symbols as in Table 2

\begin{tabular}{|c|c|c|c|c|c|c|c|c|c|c|}
\hline \multirow{3}{*}{$\begin{array}{l}\text { Max. tide } \\
\text { elevation } \\
\text { (m above } \\
\text { MSL) }\end{array}$} & \multirow[t]{3}{*}{$\begin{array}{l}\text { Frequency } \\
\qquad(\%)\end{array}$} & \multirow{2}{*}{\multicolumn{2}{|c|}{$\begin{array}{l}\text { Area flooded } \\
\qquad\left(\times 10^{3} \mathrm{~m}^{2}\right)\end{array}$}} & \multicolumn{7}{|c|}{ Net fluxes for total marsh ${ }^{\mathrm{d}}\left(\mathrm{g} \mathrm{C} \mathrm{h}{ }^{-1}\right)$} \\
\hline & & & & \multicolumn{3}{|c|}{ With crabs } & \multicolumn{3}{|c|}{ Without crabs } & \multirow{2}{*}{$\begin{array}{c}\text { Crab effects } \\
\text { Net }\end{array}$} \\
\hline & & $\begin{array}{l}\text { Tidal } \\
\text { creek }\end{array}$ & $\begin{array}{l}\text { Marsh } \\
\text { flats }\end{array}$ & $\begin{array}{l}\text { TOC } \\
\text { flux }\end{array}$ & $N P^{i}$ & Net & $\begin{array}{l}\text { TOC } \\
\text { flux }\end{array}$ & $N P^{\prime}$ & Net & \\
\hline 0.7 & 96 & 0 & 0 & 0 & -623 & -623 & 0 & -2154 & -2154 & 1531 \\
\hline 0.8 & 87 & 0.03 & 2.48 & +397 & -623 & -226 & +247 & -2154 & -1907 & 1681 \\
\hline 1.0 & 62 & 1.40 & 5.07 & +937 & -623 & +314 & +605 & -2154 & -1549 & 1863 \\
\hline 1.2 & 33 & 9.77 & 5.74 & +1789 & -623 & +1166 & +1274 & -2154 & -880 & 2046 \\
\hline 1.4 & 12 & 17.28 & 6.72 & +2618 & -623 & +1995 & +1916 & -2154 & -238 & 2233 \\
\hline 1.6 & 3 & 27.2 & 6.80 & +3519 & -623 & +2896 & +2642 & -2154 & +488 & 2408 \\
\hline 1.8 & 1 & 34.44 & 7.56 & +4288 & -623 & +3665 & +3241 & -2154 & +1087 & 2578 \\
\hline \multicolumn{11}{|c|}{$\begin{array}{l}\text { Frequency with which tides inundating the marsh reach elevation; based on } 12 \text { mo continuous water level records measured } \\
\text { at the junction of the marsh and estuary in the field (Taylor 1988) } \\
\text { 'Based on surveys of areal extent of marsh inundation by } 14 \text { tides (Taylor 1988) } \\
\text { 'Calculated by multiplying hourly TOC flux and community NP values from Table } 6 \text { with area of each region inundated at } \\
\text { high tide } \\
\text { ' Includes exposed plus inundated regions } \\
\text { e Values in presence of crabs minus values in absence of crabs } \\
\text { 'Rates assumed to be the same whether marsh inundated or not }\end{array}$} \\
\hline
\end{tabular}


for all except the lowest ( $0.8 \mathrm{~m}$ above MSL) tides, and this accounts for $87 \%$ of the tides inundating the marsh (Taylor 1988).

In conclusion, the crab community appears to have considerable impact on the carbon fluxes across the surface of this marsh. For the marsh as a whole, the 2 species enhanced the net loss of carbon, Cleistostoma edwardsii by increasing TOC fluxes, and Sesarma catenata by reducing epibenthic NP. The quantity of organic carbon mobilized from the tidal creek by $C$. edwardsii ( $163 \mathrm{~g} \mathrm{C} \mathrm{m}^{-2} \mathrm{yr}^{-1}$ ) was approximately 30 times the annual TOC flux from the entire marsh to the estuary $15 \mathrm{~g} \mathrm{C} \mathrm{m}^{-2} \mathrm{yr}^{-1}$, Taylor 1988). Similarly, the reduction in epibenthic carbon fixation $\left(96 \mathrm{~g} \mathrm{C} \mathrm{m}^{-2} \mathrm{yr}^{-1}\right.$ ) caused by $S$. catenata was equivalent to almost $25 \%$ of the annual net production of $S$. perennis $(390 \mathrm{~g} \mathrm{C}$ $\mathrm{m}^{-2} \mathrm{yr}^{-1}$; Christie 1981). The overall impacts of the crabs were sufficient to determine the direction of net flux of carbon, and depending on tide elevation, whether the marsh functioned as a carbon source or $\sin k$.

Acknowledgements: Thanks are extended to L. Christmas and $\mathrm{H}$. Barber for technical assistance. The research was funded by a Doctoral Bursary from the Foundation for Research Development, South Africa.

\section{LITERATURE CITED}

Agosta, K. (1985). The effect of tidally induced changes in the creekbank water table on pore water chemistry. Estuar coast. Shelf Sci. 21: 389-400

Allanson, B. R., Read, G. H. L. (1987). The response of estuaries along the southeastern coast of southern Africa to marked variation in freshwater inflow. Special Report No. 2/87, Institute for Freshwater Studies, Rhodes University, Grahamstown

Bell, S. S., Watzin, M. C., Coull, B. C. (1978). Biogenic structure and its effects on the spatial heterogeneity of meiofauna in a salt marsh. J. exp. mar. Biol. Ecol. 35: 99-107

Bertness, M. D. (1985). Fiddler crab regulation of Spartina alterniflora production on a New England marsh. Ecology 66: $1042-1055$

Bertness, M. D., Miller, T (1984). The distribution and dynamics of Uca pugnax burrows in a New England salt marsh. J. exp. mar. Biol. Ecol. 83: 211-237

Cammen, L. M., Seneca, E. D., Stroud, L. M. (1980). Energy flow through the fiddler crabs Uca pugnax and U. minax and the marsh periwinkle Littorina irrorata in a North Carolina salt marsh. Am. Midl. Nat. 1.03: 238-250

Cammen, L. M., Seneca, E. D., Stroud, L. M. (1984). Longterm variation of fiddler crab populations in North Carolina salt marshes. Estuaries 7: 171-175

Christie, N. D. (1.981). Primary production in Langebaan Lagoon. In: Day, J. H. (ed.) Estuarine ecology with particular reference to southern Africa. Balkema, Cape Town, p. 101-115

Chrzanowski, T. H., Spurrier, J. D., Dame, R. F., Zingmark, R. $G$. (1986). Processing of microbial biomass by an intertidal reef community. Mar. Ecol. Prog. Ser. 30: 181-189
Colby, D. R., Fonseca M. S. (1984). Population dynamics, spatial dispersion and somatic growth of the sand fiddler crab Uca pugilator. Mar. Ecol. Prog. Ser. 16: 269-279

Dame, R. F., Chrzanowski, T., Bildstein, K., Kjerfve, B., McKellar, H., Nelson, D., Spurrier, J., Stancyk, S., Stevenson, H., Vernberg, J., Zingmark, R. (1986). The outwelling hypothesis and North Inlet, South Carolina. Mar. Ecol. Prog. Ser. 33: 217-229

Dame, R. F., Zingmark, R. G., Haskin, E. (1984). Oyster reefs as processors of estuarine materials. J. exp. mar. Biol. Ecol 83: $239-247$

DePatra, K. D., Levin, L. A. (1989). Evidence of the passive deposition of meiofauna into fiddler crab burrows. J. exp. mar. Biol. Ecol. 125: 173-192

Foreman, K. (1985). Do predators, resources or physical factors control the seasonal cycle of meiofauna of marshes? Estuaries 8: 48

Genoni, G. P. (1991). Increased burrowing by fiddler crabs Uca rapax (Smith) (Decapoda: Ocypodidae) in response to low food supply. J. exp. mar. Biol. Ecol. 147: 267-285

Gleason, M. L., Elmer, D., Pien, M., Fisher, J. (1979). Effects of stem density upon sediment retention by salt marsh cord grass, $S$. alterniflora Loisel. Estuanes 2: 171-173

Graneli, W. (1979). The influence of Chironomus plumosus on the exchange of dissolved substances between sediment and water. Hydrobiologia 66: 149-159

Hodgson, A. N. (1987). Distribution and abundance of the macrobenthic fauna of the Kariega estuary. S. Afr. J. Zool 22: $153-162$

Hoffman, J. A., Katz, J., Bertness, M. D. (1984). Fiddler crab deposit-feeding and meiofaunal abundance in salt marsh habitats. J. exp mar. Biol. Ecol. 82: 161-174

Katz, L. C. (1980). The effects of the burrowing of the fiddler crab Uca pugnax (Smith). Estuar coast. mar. Sci. 4. $233-237$

Krebs, C. T., Valiela, I. (1978). Effect of experimentally applied chlorinated hydrocarbons on the biomass of the fiddler crab, Uca pugnax (Smith). Estuar. coast. mar. Sci. 6: $375-386$

Kristensen, E. (1984a). Effect of natural concentrations on nutrient exchange between a polychaete burrow in estuarine sediments and the overlying water. J. exp. mar. Biol. Ecol. 75: $171-190$

Kristensen, E. (1984b). Oxygen and inorganic nitrogen exchange in a Nereis virens (Polychaeta) bioturbated sediment-water system. J. coast. Res. 1: 109-116

Kristensen, E., Jensen, M. H., Anderson, T K. (1985). The impact of polychaete (Nerejs virens Sars.) burrows on nitrification and nitrate reduction in estuarine sediments. J. exp. mar. Biol. Ecol. 85: 75-91

Lampert, W. (1984). The measurement of respiration. In: Downing, J. A., Rigler, F. H. (eds.) A manual of secondary productivity in fresh waters. Blackwell Scientific Publications, Oxford, p. 413-468

Matishoff, G., Fisher, J. B., Matis, S. (1985). Effects of benthic macroinvertebrates on the exchange of solutes between sediments and freshwater. Hydrobiologia 12: 1.9-33

Montague, C. L. (1982). The influence of fiddler crab burrows on metabolic processes in salt marsh sediments. In: Kennedy, V. S. (ed.) Estuarine comparisons. Academic Press, New York, p. 283--301

Nixon, S. W. (1980). Between coastal marshes and coastal waters - a review of twenty years of speculation and research on the role of salt marshes in estuarine productivity and water chemistry. In: Hamilton, R., MacDonald, K. B. (eds.) Estuarine and wetland processes. Plenum Press, New York, p. 437-525 
Ponnamperuma, F. N., Martinez, E., Loy, T. (1966). Influence of redox potential and partial pressure of carbon dioxide on $\mathrm{pH}$ values and the suspension effect on flooded soils. Soil Sci. 101: 421-431

Rasmussen, M. B., Henriksen, K., Jensen, A. (1983). Possible causes of the temporal fluctuations in primary production of the microphytobenthos in the Danish Wadden Sea. Mar. Biol. 73: 109-114

Ringold, P. (1979). Burrowing, root mat density, and the distribution of fiddler crabs in the eastern United States. J. exp. mar. Biol. Ecol. 36: 11-21

Sartory, D. P. (1985). The determination of algal chlorophyllous pigments by high performance liquid chromatography and spectrophotometry. Wat. Res. 19: $605-610$

Sorenson, J., Jorgensen, B. B., Revsbech, N. P. (1979). A comparison of oxygen, nitrate and sulfate respiration in coastal marine sediments. Microb. Ecol. 5: 105-115

South African Tide Tables. (1987). The Hydrographer. South African Navy, Maritime Headquarters, Tokai

Taylor, D. I. (1988). Tidal exchanges of carbon, nitrogen and phosphorus between a Sarcocornia salt marsh and the Kariega estuary, and the role of salt marsh brachyura in this transfer. Ph.D. thesis, Rhodes University, Grahamstown

Taylor, D. I. (1992). The influence of upwelling and short-term changes in concentrations of nutrients in the water column on fluxes across the surface of a salt marsh. Estuaries 15: $68-74$

This article was submitted to the editor
Teal, J. M. (1958). Distribution of fiddler crabs in Georgia salt marshes. Ecology 39: 185-193

Umbreit, W. W., Burris, R. H., Stauffer, J. F. (1972). Manometric techniques. Burgess, Minneapolis

Valiela, I., Teal, J. M., Deuser, W. G. (1978). The nature of growth forms in the salt marsh grass Spartina alternillora. Am. Nat. 112: 461-470

Welsh, B. L. (1980). Comparative nutrient dynamics of a marsh-mudflat ecosystem. Estuar. coast. mar. Sci. 10: $143-164$

Willason, S. W. (1981). Factors influencing the distribution and coexistence of Pachygrapsus crassipes and Hemigrapsus oregonensis (Decapoda: Grapsidae) in a California salt marsh. Mar. Biol. 64: 125-133

Williams, B. G., Naylor, E., Chatterton, T. D. (1985). The activity patterns of New Zealand mud crabs under field and laboratory conditions. J. exp. mar. Biol. Ecol. 89: 269-282

Wolf, P. L., Shamholtzer, S. F., Reimold, R. J. (1975). Population estimates for Uca pugnax (Smith, 1870) on the Duplin Estuary Marsh, Georgia, USA (Decapoda, Brachyura, Ocypodidae). Crustaceana 29: 27-196

Yamada, H., Kayama, M. (1987). Liberation of nitrogenous compounds from bottom sediments and effects of bioturbation by the small bivalve, Theora lata (Hinds.). Estuar. coast. Shelf Sci. 24: 539-555

Yelverton, G. F., Hackney, C. T. (1986). Flux of dissolved organic carbon and pore water through the substrate of a Spartina alterniflora marsh in North Carolina. Estuar. coast. Shelf Sci. 22: 255-267

Manuscript first received: July 28, 1989

Revised version accepted: April 23, 1993 